\section{Hendig oppslagsverk om nyresykdommer}

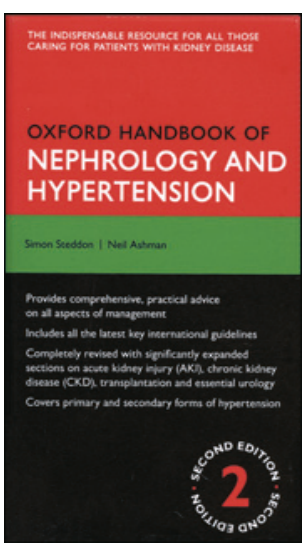

Simon Steddon, Neil Ashman

Oxford handbook of nephrology and hypertension

2 utg. 972 s, tab, ill. Oxford: Oxford University Press, 2014. Pris GBP 33

ISBN 978-0-19-965161-0

Den første utgaven av denne oppslagsboken ble publisert i 2006 . Den ble da raskt en av mine favorittbøker fordi informasjonen var kortfattet, konsis og ikke minst praktisk nyttig i en travel klinisk hverdag, når tiden ikke strakk til for et dypdykk i de store lærebøkene. Denne utgaven er blitt betydelig bedre og mer omfattende. Den gir praktisk klinisk informasjon og samtidig stor detaljrikdom.

Dette er en grei bok for alle leger som kommer i kontakt med pasienter med kronisk og akutt nyreproblematikk eller blodtrykksproblemer. Den er nok spesielt nyttig for leger i spesialisering $\mathrm{i}$ indremedisin/nyresykdommer, men også for spesielt interesserte leger i allmennpraksis. Den rommer også mye informasjon om hypertensjon og urologi.

Boken gir kompakt kunnskap, men er oppdatert og inneholder relevant informasjon om diagnostikk og behandling. Siden kunnskapen om nyresykdommer generelt er variabel og ofte oppfattes som vanskelig tilgjengelig, fyller boken et behov som er stort utenfor det miljøet som har nyresykdommer som spesialitet. Boken kan plasseres i en frakkelomme uten å gi for store nakkeproblemer den veier bare 486 gram til tross for nesten 1000 tettskrevne sider.

Bokens 14 kapitler omfatter alt fra klinisk vurdering og praktiske prosedyrer til mer detaljert kunnskap om akutt og kronisk nyreskade, hypertensjon og urologi. Både praktisk dialysebehandling og behandling av pasienter som har gjennomgått nyretransplantasjon, har fått bred plass. Ulike typer akutt nyreskade er det som er mest grundig omtalt i denne andre utgaven - det er veldig bra. Transplantasjon har fått en stor plass i forhold til tidligere, også etter min oppfatning bra. Elektrolyttforstyrrelser er konsist beskrevet, med mulige årsaksforhold, symptomatologi, nødvendige undersøkelser og klare behandlingsforslag. Noen av kapitlene er utfylt med relativt få tabeller, algoritmer, figurer og tegninger, som er relevante og bryter opp teksten.

Dette er absolutt ikke en bok man leser side for side. Det er kjedelig. Det er en bok man benytter for å få informasjon der og da om konkrete problemstillinger, derfor er det viktig at stikkordregisteret er omfattende og godt. Boken inneholder ikke referanser, og forslaget til nyttige lenker er beskjedent. Ulempen ved slike oppslagsverk er at de må oppdateres ganske ofte, og åtte år er lang tid. Boken har for øvrig vært tilgjengelig som app fra 2011, men appen er ikke oppdatert.

Jeg vil på det varmeste anbefale dette hendige oppslagsverket det vil være til nytte for både erfarne og mindre erfarne kolleger.

\section{Miljørettet helsevern i (britisk) praksis}

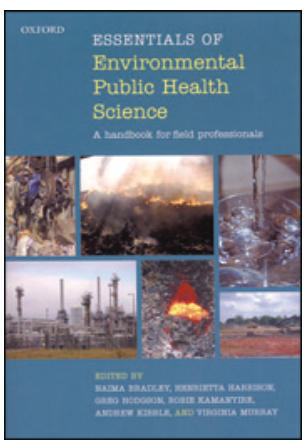

Naima Bradley, Henrietta Harrison,

Greg Hodgson et al., red.

Essentials of environmental

public health science

A handbook for field professionals. 206 s, tab, ill. Oxford: Oxford University Press, 2014. Pris GBP 30

ISBN 978-0-19-968288-1

Den sentrale helseadministrasjonen i Storbritannia er nylig omorganisert. Fra 2013 er Public Health England det utøvende organet for folkehelsearbeidet, blant annet med mandat til å styrke kompetansen innen de forebyggende tjenestene.

Denne utgivelsen er laget av Public Health England både som en ressurs for studenter og en håndbok for utøvere av lokalt miljørettet helsevern. Den gir praktiske anvisninger for hvordan man skal kartlegge potensielt helseskadelige miljøfaktorer, og hvordan man kan vurdere risiko. Den går kortfattet gjennom hvordan kunnskap om fysiokjemiske egenskaper av agens kan bidra til antakelser om helsekonsekvenser. Ett kapittel er viet risikoanalyse og risikokommunikasjon. Bruk av geografiske informasjonssystemer og metoder for miljøanalyser beskrives med vekt på praktisk anvendelse. Egne kapitler behandler luftforurensninger, vannkvalitet, bakkeforurensninger og avfallshåndtering. Det avsluttende kapitlet tar opp miljøproblematikk i en videre kontekst, som bærekraftig utvikling, klimaendringer og andre globale helsetrusler som den teknologiske utviklingen medfører.

Det sier seg selv at mange enkeltheter må utelates i en bok på omkring 200 sider, men bokens begrensede format er også dens styrke. Innholdet er godt strukturert og veksler bra mellom generelle prinsipper og eksempler på konkret anvendelse. Omfattende og oppdaterte referanser gjør det enkelt for leseren å søke ytterligere kunnskap. Boken er tenkt brukt sammen med to mer grunnleggende innføringsbøker i henholdsvis toksikologi (1) og miljøepidemiologi (2). Samlet utgjør disse bøkene en oppdatert kunnskapskilde for det tradisjonelle miljørettede helsevernarbeidet. Selv om gjennomgangen av lovverk og administrative strukturer ikke er relevant for norske forhold, er det meste av innholdet for øvrig matnyttig stoff også for norske utøvere.

En liten innvending til slutt: Forlaget har valgt en svak blåfarge på tekst og figurer, noe som gjør lesningen unødig belastende for eldre øyne.

\section{John Gunnar Mæland}

Professor emeritus, Institutt for global helse og samfunnsmedisin Universitetet i Bergen

\section{Litteratur}

1. Baker D, Karalliede L, Murray V et al. red. Essentials of toxicology for health protection. A handbook for health professionals. 2. utg. Oxford: Oxford University Press, 2012.

2. Kreis IA, Busby A, Leonardi $G$ et al. red. Essentials of environmental epidemiology for health protection. A handbook for field professionals. Oxford: Oxford University Press, 2012 